\title{
CLINICAL STUDY OF THYROID MALIGNACIES AND THE ROLE OF SERUM TSH IN PREDICTING MALIGNANCIES
}

B.A. Sathyanarayana1, Ramachandra J², Saurabh Kumar Sinha3, Nandeeshkumar G.N4, Tejasvi Kumar C5

\section{HOW TO CITE THIS ARTICLE:}

BA Sathyanarayana, Ramachandra J, Saurabh Kumar Sinha, Nandeeshkumar GN, Tejasvi Kumar C. "Clinical study of thyroid malignacies and the role of serum tsh in predicting malignancies". Journal of Evolution of Medical and Dental Sciences 2013; Vol. 2, Issue 43, October 28; Page: 8386-8392.

ABSTRACT: BACKGROUND AND OBJECTIVE: Thyroid malignancies account for $90 \%$ of endocrinal malignancies. The incidence of thyroid malignancies has increased three fold over the past 3 decades. Many patients present to the surgical outpatient department with a thyroid nodule. However not all there are many methods to diagnose and predict malignancy in a thyroid nodule. A clinical examination is always the first step to assess a nodule. A thyroid profile is also essential. This is accompanied by certain tests which increase the rate of detection. Fine needle aspiration cytology (FNAC) is the present gold standard and primary tool for assessing risk of malignancy. Other tests include ultrasonography, thyroid scintigraphy, CT scan and MRI. Recent studies have found levels of serum TSH to be an independent predictor of malignancy in thyroid nodules. This biochemical marker could be used as a screening test for malignancy. In this study we investigated the utility of TSH in predicting malignancy and the common clinical presentation of thyroid malignancies. METHODS: This prospective study included 50 patients presenting with thyroid swellings clinically suspicious of malignancy at the department of general surgery, Kempegowda Institute of Medical Sciences, Bangalore. Duration of study was June 2010 to June 2012 which included a 6 month follow up. RESULTS: Majority of patients (92\%) Presented with thyroid swelling, 25 patients (50\%) presented with a solitary nodule of thyroid and 21 patients (42\%) had a multinodular goitre. 4 patients presented with primary complaints other than a neck swelling. The next common complaint was pain and discomfort in the neck (8\%). Only 3 patients presented with compressive symptoms. Papillary carcinoma was the most common (93\%) histopathological variety of malignancy, Incidence of Follicular carcinoma was 7\%. The mean TSH value was higher in histopathologically confirmed carcinoma of thyroid. $(3.71 \pm 1.22 \mathrm{mU} / \mathrm{L})$ when compared with those with benign disease $(1.80 \pm 1.03 \mathrm{mU} / \mathrm{L})$. INTERPRETATION AND CONCLUSION: Thyroid malignancies have a varied clinical presentation. The commonest presentation being that of a solitary thyroid nodule. Though there are many predictors of thyroid malignancy, none of them can conclusively predict the nature of a thyroid nodule. In our study we evaluated the utility of preoperative serum TSH levels as a predictor of malignancy and it did show a statistically significant correlation $(\mathrm{P}=<0.01)$ between higher TSH levels and malignant nodules. However this relationship between higher TSH levels was not seen in those presenting with no primary thyroid swelling and only cervical lymph node metastasis. The utility of TSH in poorly differentiated carcinoma could not be assessed as all the patients in this series had well differentiated carcinoma.

KEY WORDS: THYROID MALIGNENCY, TSH, PAPILLARY CARCINOMA, SOLITARY NODULE.

INTRODUCTION: Thyroid diseases have always been an enigma, the management of thyroid disease has undergone a tremendous changes over the ages, from the crude surgeries of the ancient time to 
the multidisciplinary approach of the modern era, however in the present scenario surgery plays an important role in the management of malignancies. Thyroid malignancies account for $90 \%$ of endocrinal malignancies. The incidence has increased three fold over fast three decades, many patients present to the surgical department with a thyroid nodule. There are many methods to predict malignancy in a thyroid nodule. A clinical examination is always the first step to assess a nodule. A thyroid profile is essential, FNAC is the gold standard. Other tests includes ultrasound, thyroid scintigraphy, C T scan, MRI. Recent studies have found TSH levels to be an independent predictor of malignancy. In the study we investigated the utility of TSH in predicting malignancy and the common clinical presentation of thyroid malignancies.

MATERIAL AND METHODS: The main objective of our study is

1. To evaluate the utility of Serum TSH estimation as a biochemical predictor of malignancy in suspicious thyroid nodule.

2. To study the clinical presentation and management of various thyroid malignancies.

This was a prospective study done in the department of general surgery. The study period was from June 10 to June 12 which included no of 50 patients with thyroid swellings clinically suspicious of malignancy.

\section{Inclusion criteria:}

1. Cases presenting with thyroid swellings clinically suspicious of malignancies including those with metastasis.

2. At least one FNAC done at the time of initial presentation

3. Thyroid profile especially TSH level measured before any medical intervention.

4. All cases must be clinically and biochemically euthyroid.

\section{Exclusion criteria:}

1. Those cases not in euthyroid state.

2. Those cases in which FNAC was not done.

All patients were admitted and detailed history and clinical examination was done and investigated. Informed consent was taken and thyroid profile, FNAC was done in all cases. All cases that gave consent for surgery were explained about the risk and complications of surgery and anesthesia, a pre op indirect laryngoscopy was done in all cases to check the status of the vocal cords. The type of surgery depended on the clinical diagnosis and FNAC report, co relation of the clinical diagnosis, pre operative TSH levels, cytology and the final histopathological diagnosis was done. Follow up was done at regular intervals by clinical examination, serum TSH levels, serum thyroglobulin estimation and thyroid scan. A clinical study with a sample size of 50 patients which included those patients presenting with clinical features suggestive of thyroid malignancy. The pre op TSH levels were analyzed to check for any relationship between TSH levels and likelihood of a thyroid nodule being malignant. The observed results were subjected to statistical analysis and the following observations were made.

OBSERVATIONS: Out of the 50 patients, 42 were females and 8 were males. The ages ranged from 17 years to 85 years with 32 percent presenting in the $4^{\text {th }}$ decade. Most patients presented with 
rapidly growing thyroid swelling of duration of two years in those patients with histologically proven thyroid malignancy median duration was 2 years. 25 patients presented with solitary nodule and 21 with multi nodular goiter , 4 with primary complaints other than neck swelling, $8 \%$ presented with pain and discomfort in the neck , 3 patients with compression symptoms , $50 \%$ presented with solitary nodule with majority involving left lobe . Incidence of malignancy was $36 \%$ overall. The incidence of malignancy in MNG was 19\%. $20 \%$ had neck nodules and 1 patient presented with bony metastasis only 7 out of 17 patients those had thyroid malignancy were picked up by clinical examination. The sensitivity of clinical examination to detect malignancy was $41 \%$. One patient initially diagnosed as malignancy turned out to be colloid goiter. The most common FNAC was colloid goiter. The most common surgery was total thyroidectomy with central neck lymph node dissection. All patients were euthyroid. The mean TSH value was $2.39+/-1.42 \mathrm{mu} / \mathrm{l}$. The mean TSH value was higher in histopathologically confirmed CA Thyroid $(3.71+-1.22 \mathrm{mu} / \mathrm{l})$ when compared with those with benign disease (1.8+-1.03 mu/l).

\begin{tabular}{|c|c|c|c|}
\hline TSH & $\begin{array}{c}\text { Histopathologically } \\
\text { confirmed colloid goiter }\end{array}$ & $\begin{array}{c}\text { Histopathologically } \\
\text { confirmed carcinoma }\end{array}$ & P value \\
\hline Min-Max & $0.43-4.42$ & $1.72-5.28$ & $\mathrm{t}=5.124 ; \mathrm{P}<0.001$ \\
\hline Mean+-SD & $1.80+-1.03$ & $3.71+-1.22$ & \\
\hline 95\%CI & $1.36-2.24$ & $3.00-4.42$ & \\
\hline \multicolumn{3}{|c|}{ Table no 1: Comparisons of TSH values according to } \\
histopathologically confirmed colloid goiter and carcinoma.
\end{tabular}

\begin{tabular}{|c|c|c|c|}
\hline TSH values & Number of patients & $\begin{array}{c}\text { Number of patients } \\
\text { with malignancy }\end{array}$ & $\%$ \\
\hline $0.40-1.39$ & 16 & 0 & 0.0 \\
\hline $1.40-4.99$ & 30 & 11 & 36.7 \\
\hline$>5.0$ & 4 & 3 & 75.0 \\
\hline Inference & $\begin{array}{l}\text { Incidence of malignancy is significantly } \\
\text { associated with higher range of TSH with p<0.001 }\end{array}$ & \\
\hline \multicolumn{2}{|c|}{$\begin{array}{c}\text { Table no 2: Incidence of malignancy according to TSH values in patients studied. } \\
\text { The statistical method used was descriptive and inferential statistical analysis. }\end{array}$} \\
\hline
\end{tabular}

DISCUSSION: There are many predictors of malignancy in a thyroid nodule. The history of prior radiation exposure especially during childhood is known to be found in many cases of papillary carcinoma. Similarly exposure to certain environmental risk factors such as excess dietary intake of iodine, retinol and vitamin E shown to have an increased chance of malignancy. In the presence of certain clinical signs and symptoms that is hard and fixed nodules, large nodules with more than 4 cms with presence of neck lymph nodes, rapid increase in size of nodules, associated hoarseness of voice, dysphagia, dyspnoea, horner's syndrome malignancy should always be suspected . Suspicious criteria by ultrasound include central hyper vascularity, micro calcification less than $2 \mathrm{~mm}$ In diameter, irregular borders and invasion in to surrounding tissues. Ultrasound scan is more sensitive than clinical examination in the detection of enlarged cervical nodes. Ser um TSH levels is a novel method in predicting malignancy. Many studies have shown a definite relation between pre op 
TSH levels and thyroid malignancy. Furthermore pre operative serum TSH concentrations are higher in more aggressive tu mors. The following is the rationale behind choosing TSH levels as predictor of malignancy. TSH is a known thyroid growth factors, well differentiated thyroid cancers express TSH receptors. Although oncogenes and other growth factors are involved in thyroid growth and development. It seems probable that TSH can act as a cancer stimulus. This hypothesis is supported by improved survival in thyroid cancer patients treated with suppressive doses of l-thyroxin and by cases of tumor growth post T4 withdrawal. Some studies have shown higher serum TSH levels associated with advanced cases of thyroid cancer. These findings suggest TSH may play a central role in development and progression of thyroid cancers. In our study we had a totally of 50 patients who presented with clinical features suspicious of thyroid malignancy. In the study the mean pre operative TSH value was $(2.39+-1.42)$. All patients were euthyroid, the mean TSH value was significantly higher in malignancy than in benign disease that is $3.71+-1.22 \mathrm{mu} / \mathrm{l} \mathrm{vs} 1.8+-1.03 \mathrm{mu} / \mathrm{l}$. This is comparable to the results of Haymart et all 2008 and Jonklass et al. 2008 (This is shown in table 3).

\begin{tabular}{|c|c|c|c|c|}
\hline Authors & Journal & $\begin{array}{c}\text { No of } \\
\text { patients }\end{array}$ & Country & Significant findings \\
\hline $\begin{array}{l}\text { Boelaert } \\
\text { et al (2006) }\end{array}$ & $\begin{array}{l}\text { Journal of clinical } \\
\text { endocrinology and } \\
\text { metabolism }\end{array}$ & 1500 & UK & $\begin{array}{l}\text { Serum TSH is independent predictor of } \\
\text { malignancy in thyroid nodules. Risk of } \\
\text { malignancy rises in parallel with serum } \\
\text { TSH within normal range. }\end{array}$ \\
\hline $\begin{array}{l}\text { Haymart } \\
\text { et al(2008) }\end{array}$ & $\begin{array}{l}\text { Journal of clinical } \\
\text { endocrinology and } \\
\text { metabolism }\end{array}$ & 843 & US & $\begin{array}{l}\text { Likelihood of thyroid cancer increases } \\
\text { with higher TSH concentration .Higher } \\
\text { serum TSH associated with advanced } \\
\text { stage differentiated thyroid cancer. }\end{array}$ \\
\hline $\begin{array}{l}\text { Jonklass } \\
\text { et al (2008) }\end{array}$ & Thyroid & 50 & US & $\begin{array}{l}\text { Higher TSH concentrations are associated } \\
\text { with diagnosis of thyroid cancer. Patients } \\
\text { with thyroid cancer have lower serum } \\
\text { total T3 concentrations. }\end{array}$ \\
\hline $\begin{array}{l}\text { Polyzos } \\
\text { et al (2008) }\end{array}$ & $\begin{array}{l}\text { Journal of cancer } \\
\text { research and } \\
\text { clinical oncology }\end{array}$ & 565 & Greece & $\begin{array}{l}\text { Higher rates of thyroid malignancy in } \\
\text { patients with TSH in upper percentile of } \\
\text { normal range }\end{array}$ \\
\hline $\begin{array}{l}\text { Haymart } \\
\text { et al (2008b) }\end{array}$ & $\begin{array}{l}\text { Clinical } \\
\text { endocrinology }\end{array}$ & 1361 & US & $\begin{array}{l}\text { Thyroid cancer incidence co relates with } \\
\text { Serum TSH independent of age. Higher } \\
\text { TSH is associated with extra thyroidal } \\
\text { extension of disease. }\end{array}$ \\
\hline $\begin{array}{l}\text { Fiore } \\
\text { et al (2009) }\end{array}$ & $\begin{array}{l}\text { Endocrine related } \\
\text { cancer }\end{array}$ & 10178 & Italy & $\begin{array}{l}\text { Higher TSH in patients with T3- } \\
\text { T4 disease and in those with lymph node } \\
\text { metastasis. Autonomously functioning } \\
\text { thyroid nodules are less likely to be } \\
\text { malignant. }\end{array}$ \\
\hline
\end{tabular}


On analysis of the pre operative TSH values it is observed that TSH value is independent predictor of malignancy . Patients with values of $0.45-1.49 \mathrm{mu} / \mathrm{l}$ had zero chances of malignancy . Those with range of $1.4-4.99 \mathrm{mu} / \mathrm{l}$ had $37 \%$ chances of malignancy whereas those with TSH levels more than $5 \mathrm{mu} / \mathrm{l}$ had $75 \%$ chances of malignancy. All patients with thyroid swelling undergo a thyroid function test, it is important to pay a special attention to TSH value. The relationship between TSH estimation and thyroid malignancy has been surprisingly missed by clinicians so far . Therefore it is imperative to utilize this simple biochemical test as a screening test for malignancy and thus help In the better management of thyroid malignancies.

CONCLUSIONS: Thyroid malignancies have a varied clinical presentation. The commonest presentation being that of a solitary thyroid nodule. Papillary carcinoma is the most common histopathological type. There are still some controversies regarding the management of histopathologically confirmed thyroid malignancies.

Though there are many predictors of thyroid malignancies, none of them can conclusively predict the nature of the thyroid nodules.

In our study we evaluated the utility of pre operative serum TSH levels as a predictor of malignancy and it did show a statistically significant co relation $(\mathrm{p}=0.01)$ between higher TSH levels and malignant nodules. However it failed to predict malignancy in certain situations. Firstly, in those presenting with no primary thyroid swelling and only lateral aberrant thyroid. Secondly, its utility in medullary carcinoma and poorly differentiated carcinoma could not be assessed as all the patients in this series had well differentiated carcinoma.

However, as all patients with a thyroid swelling undergo a thyroid function test it is important to pay special attention to TSH values. The relationship between TSH estimation and thyroid malignancies has been surprisingly missed by clinicians so far. Therefore it is imperative to utilize this simple biochemical test as a screening test for malignancy and thus help in the better management of thyroid malignancies.

\section{REFERENCES:}

1. Williams NS, Bulstrode CJK, O'Connell PR, The Thyroid and Parathyroids, Bailey \& Love's Short Practice of Surgery, 25th ed. New York: Arnold;

2. Boelaert K, Horacek J, Holder RL, et al., Serum thyrotropin concentration as a novel predictor of malignancy in thyroid nodules investigated by fine needle aspiration, J. Clin Endocrinal Metab, 2006; 91:4295-4301

3. Haymart MR, Repplinger DJ, Leverson GE, et al, Higher TSH level in thyroid nodule patients is associated with greater risks of differentiated thyroid cancer and advanced tumor stage, J Clin Endocrinal Metab, 2008;93:809-14

4. Gupta M et al, Correlation of Fine Needle Aspiration Cytology with Histopathology in the diagnosis of Solitary Thyroid Nodule, Journal of Thyroid Research, Feb 2010;

5. Stergios A. Polyzos, Marina Kita, Zoe Efstathiadou et al, Serum thyrotropin concentration as a biochemical predictor of thyroid malignancy in patients presenting with thyroid nodules, J Cancer Res Clin Oncol. 2008; 134:953-96

6. Townsend CM, Beauchamp RD, Evers BM, Mattox KL. Sabiston textbook of surgery, 18th edition, Saunders Elsevier. 
7. Oertli D, Udelsman R. Surgery of Thyroid and Parathyroid Glands. History of thyroid and parathyroid surgery. 1:1-7

8. Duffy BJ Jr, Fitzgerald PJ. Cancer of thyroid in children, A report of 28 cases. J Clinical Endocrine Metabolism 1950; 159:1007.

9. Langman J, Sadler TW, Langman's medical embryology 9th edition.

10. Skandalakis J E, Skandalakis P N, Skandalakis' Surgical Anatomy 2nd edition

11. Barrett KE, Barman SM, Boitano S, Ganong's review of medical physiology, $23^{\text {rd }}$ edition.

12. Brunton LL, Lazo JS, Parker KL, Goodman \& Gilman's The Pharmacological Basis of Therapeutics, 11 th edition.

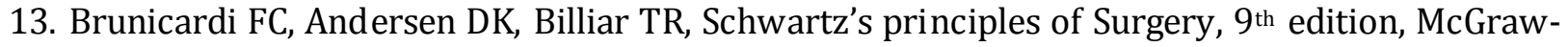
Hill

14. DeVita VT, Lawrence TS, Rosenberg SA, DeVita, Hellman, and Rosenberg's Cancer Principles \& Practice of Oncology, 8th edition, Wolters Kluwer/Lippincott Williams \& Wilkins.

15. Hay ID, et al (1998) Unilateral total lobectomy: is it sufficient surgical treatment for patients with AMES low-risk papillary thyroid carcinoma? Surgery 124:958-964; discussion 964-966

16. Mirallie E, et al (1999) Localization of cervical node metastasis of papillary thyroid carcinoma. World J Surg 23:970-973; discussion 973-974.

17. Gemsenjager E, et al (2003) Lymph node surgery in papillary thyroid carcinoma. J Am Coll Surg 197:182-190.

18. Tisell LE (1998) Role of lymphadenectomy in the treatment of differentiated thyroid carcinomas. Br J Surg 85:1025-1026.

19. Tisell LE, et al (1996) Improved survival of patients with papillary thyroid cancer after surgical micro dissection. World J Surg 20:854-859.

20. Cooper D, et al (2006) Treatment guidelines for patients with thyroid nodules and welldifferentiated thyroid cancer. American Thyroid Association. Thyroid 16:109-42

21. Rubino C, de Vathaire F, Dottorini ME, et al. Second primary malignancies in thyroid cancer patients. Br J Cancer 2003; 89:1638.

22. Greene F, Page D, Fleming I, et al.Thyroid tumors. In: Greene F, Page D, Fleming I, et al., eds. AJCC cancer staging manual, 6e. New York: Springer-Verlag, 2002:77.

23. Rosen IB, Walfish PG, Bain J, Bedard YC. Secondary malignancy of the thyroid gland and its management. Ann Surg Oncol 1995; 2:252.

24. Chen H, Nicol TL, Udelsman R. Clinically significant, isolated metastatic to the thyroid gland. World J Surg 1999; 23:177.

25. Douglas S. Ross, Predicting Thyroid Malignancy, J. Clin. Endocrinol. Metab. 2006 91:4253-4255

26. Hegedus L 2004 Clinical practice. The thyroid nodule. N Engl J Med 351:1764- 1771.

27. Mandel SJ 2004 A 64-year-old woman with a thyroid nodule. JAMA 292:2632- 2642.

28. Ross DS: Evaluation and nonsurgical management of thyroid nodule. Randolph Surgery of the thyroid and parathyroid glands. Saunders 2003.

29. Mehanna HM, Jain A, Morton RP, Watkinson J, Shaha A: Investigating the thyroid nodule. BMJ 2009, 338:705-709.

30. Stocker DJ, Burch HB 2003 Thyroid cancer yield in patients with Graves' disease. Minerva Endocrinol 28:205-212 
31. Shi Y, Zou M, Farid NR 1993 Expression of thyrotropin receptor gene in thyroid carcinoma is associated with good prognosis. Clin Endocrinol (Oxf) 39:269-274.

32. Derwahl M, Broecker M, Kraiem Z 1998 Thyrotropin may not be the dominant growth factor in benign and malignant thyroid tumors. J Clin Endocrinol Metab 84:829-834 77

33. Mazzaferri EL 2000 Thyroid cancer and Graves' disease: the controversy 10years later. Endocr Pract 6:221-225.

34. Jonklaas J, Sarlis NJ, Litofsky D, Ain KB, Bigos ST, Brierley JD, Cooper DS, Haugen BR, Ladenson PW, Magner J, Robbins J, Ross DS, Skarulis M, Maxon HR, Sherman SI 2006 Outcomes of patients with differentiated thyroid carcinoma following initial therapy. Thyroid 16:1229-124

35. Braga M, Ringel MD, Cooper DS 2001 Sudden enlargement of local recurrent thyroid tumor after recombinant TSH administration. J Clin Endocrinol Metab 86:5148-515

36. Jemal A, Siegel R, Ward E, et al. Cancer statistics, 2007. CA Cancer J Clin 2007;57:43.

37. Dorairajan N, Pandiarajan R, Yuvaraja S. A descriptive study of papillary thyroid carcinoma in a teaching hospital in Chennai, India.Asian J Surg.2002 Oct;25(4):300-3

38. Correa P, Chen VW. Endocrine gland cancer. Cancer 1995;75:338 Jossart GH, Clark OH. Welldifferentiated thyroid cancer. Curr Probl Surg 1994;31:933

39. Lansford CD, Teknos TN: Evaluation of the thyroid nodule. Cancer control 2006, 13(2):89-98.

40. Al-Ashaa Y, Hefny AF, Joshi S , Papillary thyroid carcinoma presenting as a lateral neck cyst, African Health Sciences 2011; 11(2): 296 - 300.

41. Mazzaferri EL, Jhiang SM. Long-term impact of initial surgical and medical therapy on papillary and follicular thyroid cancer. Am J Med 1994;97:418.

42. Fiore E, Rago T, Provenzale MA, Lower levels of TSH are associated to a lower risk of papillary thyroid cancer in patients with thyroid nodular disease: thyroid autonomy may play a protective role. Endocrine-Related Cancer 16 1251-1260.

\section{AUTHORS:}

1. B.A. Sathyanarayana

2. Ramachandra J.

3. Saurabh Kumar Sinha

4. Nand ees hkumar G.N.

5. Tejasvi Kumar C.

\section{PARTI CULARS OF CONTRIBUTORS:}

1. Professor, Department of General Surgery, KIMS, B angalore.

2. Professor, Department of General Surgery, KIMS, B angalore.

3. Senior Resident, Department of General Surgery, KIM S, Bangalore.
4. Junior Resident, Department of General Surgery, KIMS, Bangalore.

5. Junior Resident, Department of General Surgery, KIMS, Bangalore.

\section{NAME ADDRESS EMAIL ID OF THE CORRESPONDING AUTHOR:}

Dr. B.A. Sathyanarayana,

Professor,

Departm ent of Surgery,

KIMS, Bangalore.

Email - dr.nandeeshkumar9@gmail.com

Date of Submission: 15/10/2013.

Date of Peer Review: 16/10/2013.

Date of Acceptance: 22/10/2013.

Date of Publishing: 26/10/2013 